\title{
Stable isotopic analyses of modern benthic foraminifera from seasonally stratified shelf seas: disequilibria and the 'seasonal effect'
}

\author{
J.D. Scourse, ${ }^{1 *}$ H. Kennedy, ${ }^{1}$ G.A. Scott ${ }^{1}$ and W.E.N. Austin ${ }^{2}$ \\ $\left({ }^{1}\right.$ School of Ocean Sciences, University of Wales (Bangor), Menai Bridge, \\ Anglesey LL59 5AB, UK; ${ }^{2}$ School of Geography and Geosciences, University \\ of St Andrews, Irvine Building, North Street, St Andrews, Fife KY16 9AL, UK)
}

Received 1 February 2003; revised manuscript accepted 10 April 2004

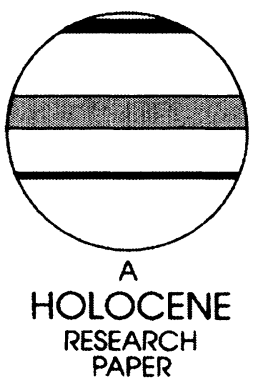

\begin{abstract}
Previously published stable isotopic data on benthic foraminiferal species from a Holocene sequence in the Celtic Sea have been interpreted in terms of the progressive replacement of a tidally mixed by a stratified water mass. Offsets in the $\delta^{18} \mathrm{O}$ data between Ammonia batavus and Quinqueloculina seminulum were attributed to a 'seasonal effect' in which these two species were hypothesized to have calcified at different times of the year. The aims of this study were to test the hypotheses (1) that benthic foraminiferal stable isotope records from across the Celtic Sea front reflect seasonal stratification and (2) that offsets in the oxygen isotope record between different species are the result of the postulated seasonal effect. Hypothesis 1 was tested through investigation of live and dead benthic foraminiferal and bottom-water $\delta^{18} \mathrm{O}$ and $\delta^{13} \mathrm{C}$ sampled in transects across the Celtic Sea front from mixed through frontal to stratified water masses. Measurements of bottom-water salinity enabled a mixing-line equation to be developed for this area enabling quantitative reconstructions of bottom-water temperature from the isotopic data. Samples from stratified settings are characterized by heavier $\delta^{18} \mathrm{O}_{\text {foram }}$ and lighter $\delta^{13} \mathrm{C}_{\text {foram }}$ values than the mixed samples. Offsets in $\delta^{18} \mathrm{O}_{\text {foram }}$ between $A$. batavus and $Q$. seminulum support the notion of the seasonal effect. A. batavus produces values close to equilibrium while $Q$. seminulum overestimates temperature by up to $2^{\circ} \mathrm{C}$ and this might explain some of the offset observed between the two species observed in the palaeodata. Comparison of the $\delta^{18} \mathrm{O}_{\text {foram }}$ data with measured seasonal temperature cycles from mixed and stratified localities in the Celtic Sea demonstrates that, while most foraminifera calcify during the summer months, different species calcify at, or are preserved from, different times within this warm part of the seasonal cycle; $Q$. seminulum calcifies during September when peak bottom-water temperatures occur, while $A$. batavus calcifies during September in stratified localities, but during spring or early summer in mixed localities. This study confirms the interpretation of the $\delta^{18} \mathrm{O}$ palaeodata from the Celtic Sea as a palaeostratification record and demonstrates that $\delta^{18} \mathrm{O}$ data from shelf-sea cores can be used to supplement benthic foraminiferal assemblages as a tool for reconstructing the long-term dynamics of seasonal stratification.
\end{abstract}

Key words: Celtic Sea, seasonal stratification, benthic foraminifera, stable isotopes, isotopic disequilibria, shelf sea, palaeoceanography.

\section{Introduction}

Although continental shelves account for just $10 \%$ of the ocean-floor area, shelf seas contribute $20 \%$ or more of primary marine productivity and are therefore a significant component of the global carbon cycle; net primary production in shelf seas has been estimated at around $6 \times 10^{9}$ tons $\mathrm{yr}^{-1}$ (Walsh et al., 1981; Wollast, 1991). Much of this primary production is

* Author for correspondence (e-mail: j.scourse $(\hat{a})$ bangor.ac.uk) associated with seasonal stratification and shelf-sea fronts (Berger et al., 1989). Such seasonal thermal stratification is the dominant hydrodynamic phenomenon of tide-dominated shelf seas in the middle and high latitudes. Stratification occurs when summer heating of the sea surface exceeds tidal stirring, and the resultant fronts, separating mixed from stratified water, are zones of enhanced primary production and support a coupled pelagic-benthic ecosystem which influences organic sedimentation and the production/preservation of microfossils. 
Data on the palaeostratification dynamics of shelf seas are, however, rare, but Austin and Scourse (1997) and Scourse et al. (2002) provide AMS ${ }^{14} \mathrm{C}$ dated Holocene benthic foraminiferal faunal and stable isotopic data from the central Celtic Sea (British Geological Survey [BGS] vibrocore 51/-07/199; Figure 1) which they interpret as a record of the replacement of tidally mixed by stratified waters in the early Holocene. The core generating this record was recovered from within the area covered by stratified water during the summer months at the present day; at this location the water mass stratifies during May and mixes again during October (Elliott $e t$ al., 1991). Marked positive trends in the stable oxygen isotopic data (Austin and Scourse, 1997) from the benthic calcareous foraminifers Ammonia batavus and Quinqueloculina seminulum (Figure 2) were interpreted as a $4-5^{\circ} \mathrm{C}$ cooling in bottomwater temperature caused by the seasonal replacement of tidally well-mixed water by stratified water between 8990 and $8440 \mathrm{yr}$ cal. BP $(8720 \pm 2 \sigma$; Scourse et al., 2002). Stable carbon isotopic data from the same species, measured through the same core intervals, showed a negative trend consistent with decomposition of organic matter and oxygen consumption beneath the productive frontal zone separating tidally mixed from stratified water masses. The foraminiferal faunal analyses, in the light of modern foraminiferal distributional data (Scott et al., 2003), also support the inference that the succession can be interpreted as a response to the progressive seasonal stratification of the Celtic Sea during the Holocene. In particular, the faunal data highlight the value of key taxa as indicators of shelf palaeostratification in the geological record, notably of Textularia bocki and Stainforthia fusiformis as mixed-frontal and frontal-stratified indicators, respectively. The critical change to this frontal assemblage occurs at the same core depth as the isotopic threshold, based on the mixing/bioturbation model adopted in Scourse et al. (2002). The faunal data therefore support the interpretation of the isotopic record as registering bottom-water temperature and water-column productivity changes driven by the evolution of seasonal stratification. The clear association between grain size and sedimentation, and these isotopic and faunal data, indicates that Holocene mud sequences preserved on continental shelves are preferentially the product of sedimentation under seasonally stratified rather than mixed water masses.

Austin and Scourse (1997) noted offsets in the 51/-07/199 $\delta^{18} \mathrm{O}$ between $Q$. seminulum and $A$. batavus (Figure 2) which they attributed to a seasonal effect in which the two species calcified at different stages of the temperature cycle. They suggest that the more positive record for $A$. batavus indicates that this species calcifies its test during the peak phase of summer heating and strongest thermocline development (Bowers and Simpson, 1990), while $Q$. seminulum growth is earlier, later, over a longer period, or any combination of these. Among others, Murray (1991) and Scott et al. (2003) have discussed periodic changes in the standing crop of shallow benthic foraminifera, particularly in response to phytoplankton blooms. If this seasonal effect interpretation is correct, therefore, the $A$. batavus $\delta^{18} \mathrm{O}$ signal registers cooler bottom-water conditions than $Q$. seminulum.

Many calcareous foraminifera, such as $A$. batavus, have a bilamellar, perforate test wall (Hansen, 1999). Calcification, associated with the process of chamber formation, is well established for foraminifera (e.g., Bé et al. 1979; Hemleben et al., 1989). As each new chamber is formed, calcification occurs on both the inner and outer surface of an organic template, leading to the formation of a thin inner lamella and a thicker outer lamella (Debenay et al., 2000). With the addition of each new chamber, a layer of calcite is also deposited over the outside of the previously formed test.

Foraminifera are known to respond to the available 'labile' (sensu Middleburg et al., 1993) organic carbon at the sea floor; useful reviews from the deep sea can be found in Gooday (1994) and Austin and Evans (2000). For example, Alve and Murray (1994) have traced the impact of the spring phytoplankton bloom on foraminiferal abundance in a mesotidal inlet in southern England. Similar studies (e.g., Altenbach, 1992) have shown that different species respond very differently to the trends in primary production. Lampitt (1985) has demonstrated from regions of high seasonality that a substantial portion of the phytoplankton bloom may

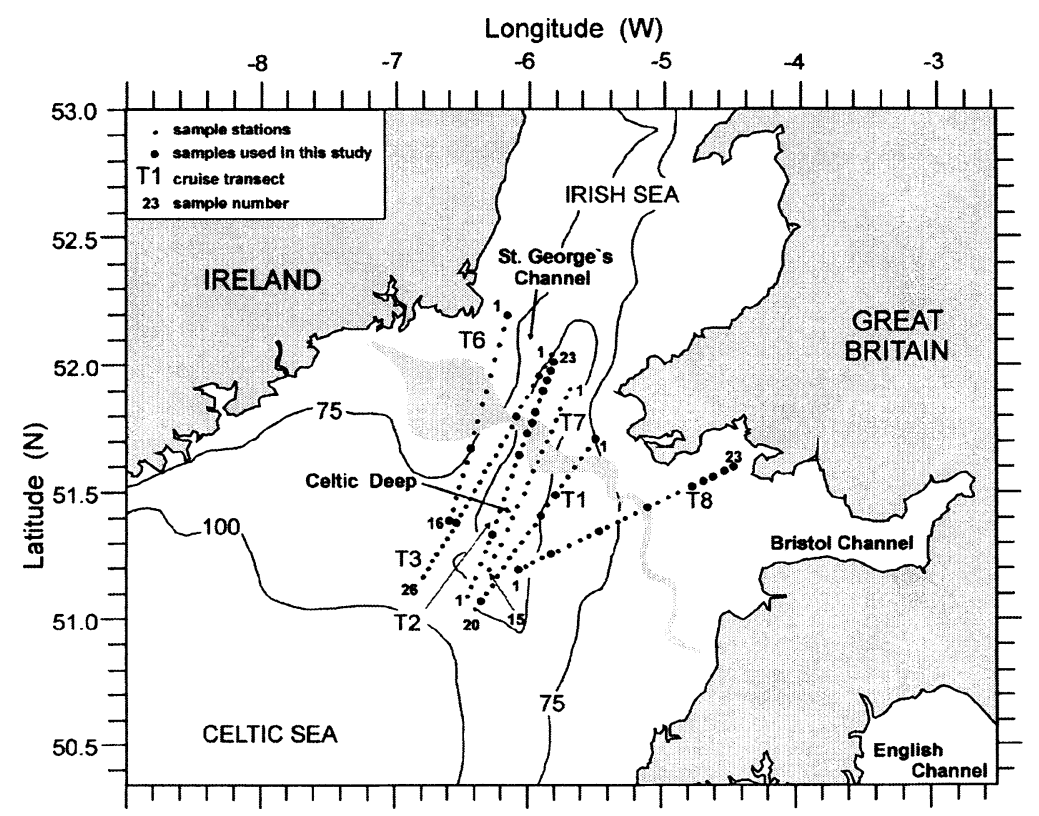

Figure 1 Location map: 51/-07/199, Celtic Sea, cruise tracks, surface sample sites and bottom-water sampling stations. Shading indicates the mean position of the Celtic Sea tidal mixing front at the present day. Isobaths in metres below mean sea level. 

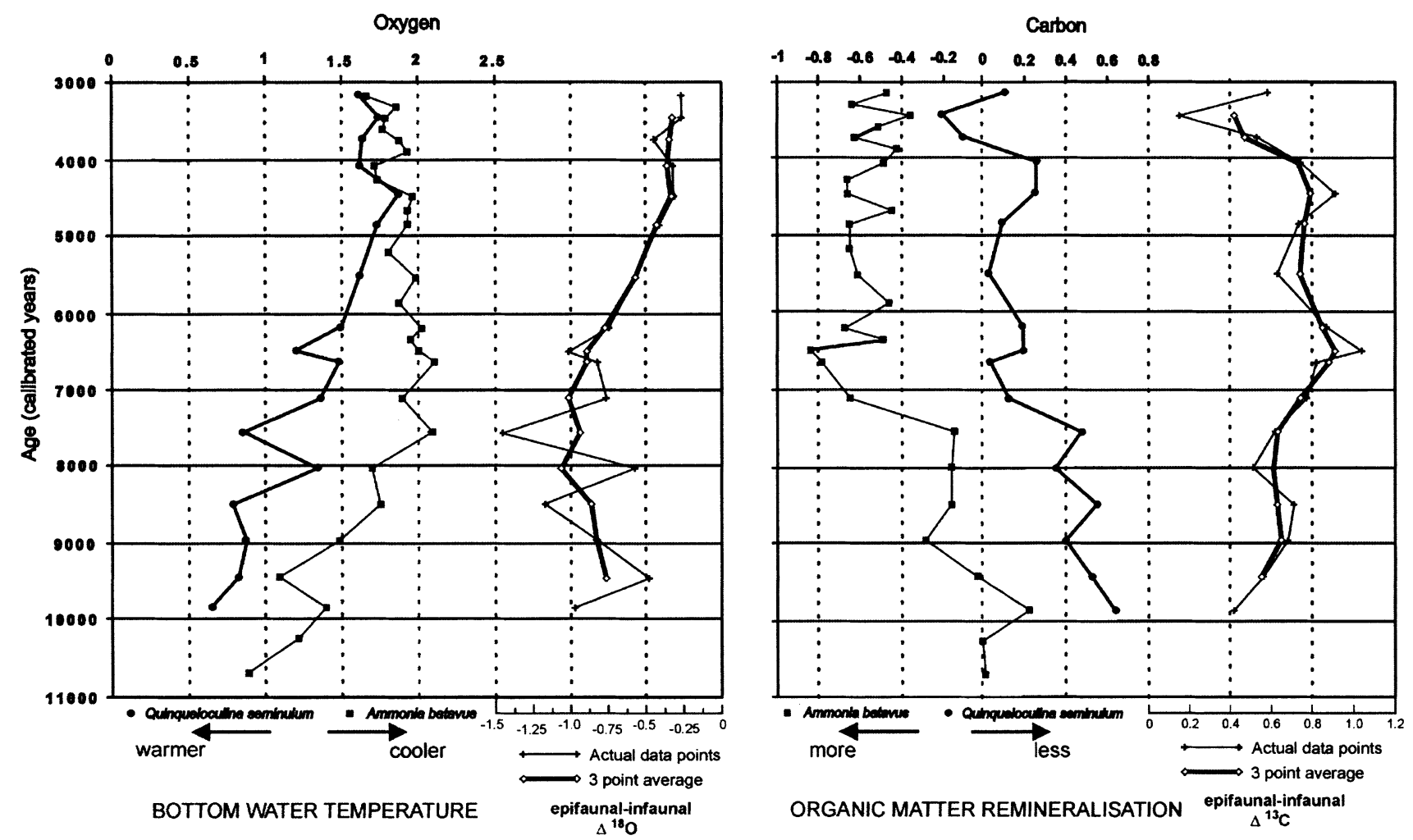

Figure 2 Isotope record $51 /-07 / 199$ by calibrated age including $\Delta^{18} \mathrm{O}$ and $\Delta^{13} \mathrm{C}$.

reach the benthos. Under conditions of higher average annual productivity, Loubere and Fariduddin (1999) have demonstrated a large seasonality signal in benthic foraminiferal assemblages.

Therefore, test growth is episodic and each episode of chamber growth can be considered as a separate instar (Smout, 1954). The test as a whole provides an integrated record of calcification throughout the growth history of the foraminifera, preserving information on, for example, seawater temperature changes over this time. The seasonal growth mechanism, possibly triggered by phytoplankton productivity, provides a plausible explanation for the seasonal effect in the benthic foraminiferal $\delta^{18} \mathrm{O}$ data.

Clearly this interpretation of the palaeo $\delta^{18} \mathrm{O}$ data from the Celtic Sea (Austin and Scourse, 1997; Scourse et al., 2002) requires calibration through measurements of stable isotopes from live benthic foraminifera inhabiting mixed, frontal and stratified localities, and also of bottom waters. The purpose of this paper is to present the results of such analyses and therefore provides a basis for a critical evaluation of the seasonal effect postulated by Austin and Scourse (1997).

\section{Aims and objectives}

The overall aims of this study were to test the following hypotheses: (1) that benthic foraminiferal stable isotope records from across the Celtic Sea front reflect seasonal stratification; (2) that offsets in the oxygen isotope record between different species are the result of a 'seasonal effect' in which different species calcify at different times of the year.

Hypothesis 1 was tested through investigation of live and dead benthic foraminiferal and bottom-water $\delta^{18} \mathrm{O}$ and $\delta^{13} \mathrm{C}$ sampled in transects across the Celtic Sea front from mixed through frontal to stratified water masses. Measurements of bottom-water salinity enabled a mixing-line equation to be developed for this area which facilitated quantitative reconstructions of bottom-water temperature from the isotopic data which could then be compared with direct measurements of temperature. These data also highlight the vital effects associated with some species. The temperature reconstructions from the $\delta^{18} \mathrm{O}_{\text {foram }}$ data then enabled, by comparison with measurements of seasonal bottom-water temperature change, assessment of the timing of calcification of individual species to test hypothesis 2 .

\section{Oceanographic setting}

The Celtic Sea extends from the $200 \mathrm{~m}$ isobath in the south and west of the continental shelf bordering the North Atlantic, to southern Ireland and the entrances to the Irish, Bristol and English Channels (Pugh and Thompson, 1986). The study area is restricted to part of the northern Celtic Sea between $51^{\circ}$ and $52^{\circ} 25^{\prime} \mathrm{N}$ between $4^{\circ}$ and $7^{\circ} \mathrm{W}$ (Figure 1). The St George's Channel Trough in the southern Irish Sea trends in a NW-SE SE direction into the extensive and broad Celtic Deep bathymetric basin which is included within the study area.

As in all tide-dominated shelf seas, heating of the surface waters in the Celtic Sea induces buoyancy and stability, but the turbulence generated by the action of bottom friction on tidal currents acts against this, and may generate sufficient kinetic energy to maintain vertical mixing throughout the depth of the water-column. During winter, the entire watercolumn is mixed with relatively uniform temperature, salinity and density characteristics throughout. In early spring, when heat fluxes from the atmosphere to the sea surface, a warm surface layer develops. This layer is separated from the colder bottom-waters by a sharp density gradient, the pycnocline, 
which restricts the exchange of heat and nutrients between the two water bodies (Figure 1). In the Celtic Sea, where salinities are generally high throughout, the pycnocline generally coincides with the thermocline, defined as the sharp temperature gradient between the surface and bottom-waters (Elliott $e t$ al., 1991). In autumn, as atmospheric cooling begins, the surface layer loses heat both upwards and downwards. Eventually the two layers become equal in temperature, the thermocline disintegrates and the whole water-column remixes. Variations in tidal mixing and water depth result in some areas of the shelf becoming stratified while adjacent waters are mixed; the frontal transition between the two is marked by a strong horizontal gradient.

The main tidal front in the study area is the Celtic Sea front extending between Britain and Ireland and curving southwards, at around $51^{\circ} \mathrm{N}$, along the British coast. This front can be recognized in summer by temperature measurements across the boundary area and is recorded by satellite imagery which detects the sharp, horizontal, surface temperature gradients (Simpson and Bowers, 1979). The mixed zone is confined to the shallower (generally $<100 \mathrm{~m}$ ) inshore waters in the north and east of the study area, whereas the deeper water over the central and outer shelf stratifies during the summer months.

The 'classical' phytoplankton cycle for seasonally stratified waters is characterized by a spring bloom followed by a subdominant autumn bloom. In winter there are few phytoplankton living because, although there is a high availability of nutrients, individuals are mixed below the euphotic zone and this reduces time available for photosynthesis. In spring, light input increases and the wind-mixed layer shallows until it no longer exceeds the critical depth (Sverdrup, 1953), the phytoplankton experience high levels of illumination and the bloom is triggered.

\section{Methods}

The samples used in this study were collected in the northeast Celtic Sea during cruises aboard the RV Prince Madog in June-July 1995 and June 1996. Shipek grab samples for surface live and dead foraminifera were collected from stations arranged along transects 1,2 and 3 in 1995, and along transects 6, 7 and 8 in 1996 (Figure 1). The transects all intersected the Celtic Sea front in, approximately, a north-south direction except transect 8 which traversed the entrance to the Bristol Channel and the front from approximately west to east. The results of the faunal analyses, and their statistical analysis, are presented in Scott et al. (2003). Care was taken to ensure that only the surface $(c .0 .5 \mathrm{~cm})$ of each sample was subsampled. Samples for foraminiferal analysis were preserved in ethanol, to which rose Bengal stain was added in order to discriminate between live and dead individuals. The temperature, salinity and density characteristics of the entire watercolumn were measured for each station using a Neil Brown Mk IIIb profiling conductivity, temperature and depth probe (CTD). A water-collection facility on the CTD was triggered to collect a water sample close (within $10 \mathrm{~m}$ ) to the sea bed. A ration of the collected water was used to calibrate the CTD while the remainder was transferred to a glass, rubbersealed, screwtop $250 \mathrm{ml}$ bottle for oxygen isotopic analysis. The bottle was bottom-filled by nalgene tube and at least three times the bottle capacity was allowed to overflow to eliminate all air bubbles before tube removal and capping.

High-quality samples of the bottom water and sedimentwater interface were procured using a Bowers and Connelly Midicorer Mark 1-400. This multicorer assembly contains four
$0.5 \mathrm{~m}$ long $9.9 \mathrm{~cm}$ diameter transparent perspex core tubes which enable undisturbed inspection of samples on recovery.

In preparation for examination under a microscope, the foraminiferal samples were washed through a $63 \mu \mathrm{m}$ sieve and dried overnight. Flotation was carried out according to Meldgaard and Knudsen (1991) using carbon tetrachloride $\left(\mathrm{CCl}_{4}\right)$ which, with a specific gravity of $1.66 \mathrm{gcm}^{-1} \mathrm{~s}^{-1}$, is considered appropriate for recent sediments; residues were checked for nonfloating tests. Foraminifera were picked and identified using light microscopes. Identifications were based on a number of taxonomic sources (Haynes, 1973; Murray, $1971 ; 1991 ; 2000)$ and reference slides held at the School of Ocean Sciences, University of Wales (Bangor).

The isotopic composition of the water, $\delta^{18} \mathrm{O}_{\text {seawater, was }}$ determined using a modification (Frew et al., 2000) of the conventional $\mathrm{CO}_{2}-\mathrm{H}_{2} \mathrm{O}$ equilibration method (Epstein and Mayeda, 1953). The analyses were made on a VG ISOGAS SIRA II mass spectrometer at the School of Ocean Sciences UWB, calibrated against VPDB using NBS19. Samples were run in batches of eight against an internal standard (Norwich Tap Water), with final values expressed relative to SMOW. Analytical accuracy was $0.05 \%$.

A temperature predicted, from equilibrium isotopic fractionation between water and foraminifera, was generated by firstly converting $\delta^{18} \mathrm{O}_{\text {seawater to }}$ the VPDB scale (Friedman and O'Neil, 1977), now reported as $\delta^{18} \mathrm{O}_{\mathrm{w}}$ :

$$
\delta^{18} \mathrm{O}_{\mathrm{w}}=\left(\delta^{18} \mathrm{O}_{\text {seawater }}{ }^{*} 0.99978\right)-0.22
$$

Temperature was subsequently calculated using the palaeotemperature equation of O'Neil et al. (1969):

$\mathrm{T}=16.9-4.38\left(\delta^{18} \mathrm{O}_{\text {foram }}-\delta^{18} \mathrm{O}_{\mathrm{w}}\right)+0.1\left(\delta^{18} \mathrm{O}_{\text {foram }}-\delta^{18} \mathrm{O}_{\mathrm{w}}\right)^{2}$

where $\mathrm{T}\left({ }^{\circ} \mathrm{C}\right)=$ temperature and $\delta^{18} \mathrm{O}_{\text {foram }}(\%)=$ the isotopic value of a foraminiferal sample relative to VPDB.

Measurement of the $\delta^{18} \mathrm{O}_{\text {foram }}$ and $\delta^{13} \mathrm{C}_{\text {foram }}$ values involved the gentle crushing of samples and transfer to a sealed automatic preparation system where the $\mathrm{CaCO}_{3}$ was reacted with $100 \%$ orthophosphoric acid at $90^{\circ} \mathrm{C}$. The resulting $\mathrm{CO}_{2}$ was analysed on a VG ISOTECH PRISM at the University of Edinburgh (mostly large samples of 10-15 dead individuals) or a VG ISOTECH PRISM Series 2 at the University of Cambridge (all small samples of approximately five live individuals). The live samples $\mathrm{T} 2 \mathrm{~S} 20$ ( $Q$. seminulum), T1S02 (Cibicides lobatulus) and T2S07 (Bulimina marginata) were analysed in Edinburgh. Results were calibrated by repeated analysis of a carbonate standard, expressed relative to VPDB and corrected for different isotopic species in $\mathrm{CO}_{2}$ which have the same molecular mass (Craig, 1957). Analytical accuracy was $0.08 \%$ for $\delta^{18} \mathrm{O}$ and $0.03 \%$ for $\delta^{13} \mathrm{C}$ at Edinburgh and $0.08 \%$ for $\delta^{18} \mathrm{O}$ and $0.06 \%$ for $\delta^{13} \mathrm{C}$ at Cambridge.

\section{Results}

\section{Oxygen isotopic analysis of bottom water and mixing-line equation}

Bottom-water samples were collected during the 1995 and 1996 cruises (Table 1) from two transects that covered a wide range ( $\sim 34$ to 36 ) of salinity; transect T2 that ran from the Celtic into the Irish Sea and transect T8 from the Celtic Sea into the Bristol Channel (Figure 1). The $\delta^{18} \mathrm{O}_{\text {seawater }}$ determined during this study were supplemented by a larger data set $(n=35)$ from the Menai Strait, between the island of Anglesey and 
Table $1 \delta^{18} \mathrm{O}$ values of bottom-water samples relative to SMOW for (a) 1995 and (b) 1996 (sample locations shown on Figure 1)

\begin{tabular}{llllc}
\hline Sample & Latitude & Longitude & Temp. $\left({ }^{\circ} \mathrm{C}\right)$ & Salinity $(\%)$ \\
\hline (a) 1995 & & & & \\
T2S22 & 51.9715 & -5.874 & 11.582 & 34.894 \\
T2S21 & 51.9305 & -5.9042 & 10.649 & 35.117 \\
T2S14 & 51.6267 & -6.097 & 9.73 & 35.21 \\
T2S18 & 51.7978 & -5.984 & 9.591 & 35.303 \\
T2S17 & 51.7562 & -6.0147 & 9.674 & 35.348 \\
(b) 1996 & & & & 0.31 \\
T8S01 & 51.1717 & -6.1667 & 0.35 \\
T8S19 & 51.493 & -4.839 & 0.35 \\
T8S20 & 51.5127 & -4.7515 & 11.9412 & 35.354 \\
T8S21 & 51.5368 & -4.6648 & 12.2684 & 34.93 \\
T8S22 & 51.53 & -4.575 & 12.3524 & 34.67 \\
T8S23 & 51.568 & -4.485 & 13.2758 & 0.35 \\
\hline
\end{tabular}

the UK mainland, which represent mixing of Liverpool Bay with Irish Sea water (Owen et al., 2002). Although these latter data represent a lower salinity range than encountered during our study, when the mixing line of $\delta^{18} \mathrm{O}_{\text {seawater against salinity }}$ is propagated to higher values the data from transect $\mathrm{T} 2$ falls on or close to the mixing line (Figure 3). The difference between the samples analysed and the Owen et al. (2002) equation is less than the error of the method $(0.05 \%)$. Most of the $\delta^{18} \mathrm{O}_{\text {foram }}$ and $\delta^{13} \mathrm{C}_{\text {foram }}$ samples were from the area covered by the $\mathrm{T} 2$ transect.

The relationship derived from transect $\mathrm{T} 8$ is offset from the Owen et al. (2002) equation. Where samples with similar salinity were measured, different $\delta^{18} \mathrm{O}_{\text {seawater }}$ values were determined (Table 1), being more positive by about 0.1 to $0.2 \%$. Data from this transect cover a much wider range of salinity because of the significant gradient found along the Bristol Channel (Figure 1). Although we have no reason to exclude the data from transect $\mathrm{T} 8$, the low number of data points that would be available to develop a mixing-line equation for this area and the unexplained deviation of the $\delta^{18} \mathrm{O}_{\text {seawater }}$ at high salinity has led us to use the same mixing-line equation for all data reduction. As a result, it is possible that the temperatures calculated using isotopic measurements on the small number of foraminifera from the sites along transect T8 may be too high.

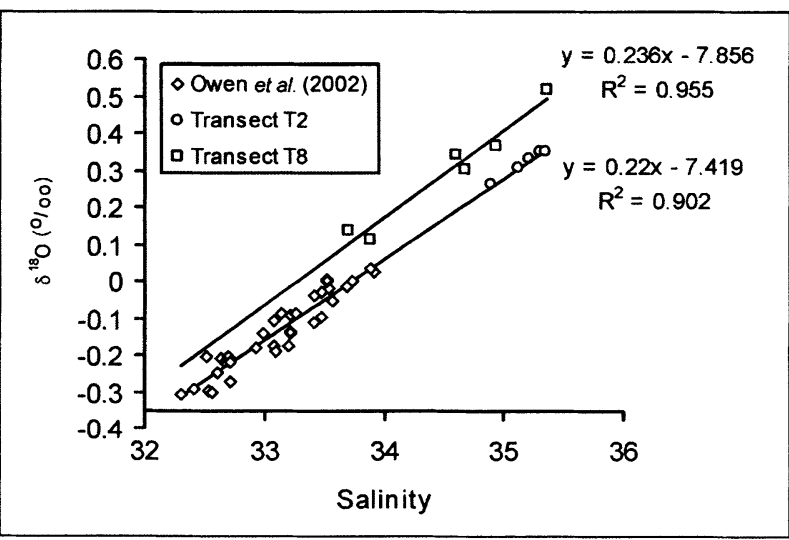

Figure 3 Linear regression of $\delta^{18} \mathrm{O}$ versus SMOW against salinity for 1995 data (transect T2) and 1996 data (transect T8) compared with a larger data set from Liverpool Bay (Owen et al., 2002). These latter data represent a lower salinity range than described in this study, but when the mixing line of $\delta^{18} \mathrm{O}_{\text {seawater against salinity for Liverpool }}$ Bay is propagated to higher values the data from transect $\mathrm{T} 2$ falls on or close to the mixing line.

\section{Isotopic measurements of foraminifera from surface samples}

The distribution of the live and dead foraminifera from the Celtic Sea samples is presented and discussed in Scott et al. (2003). A range of live and dead foraminifera were selected from these samples, in which they were most abundant, for isotopic analysis. These included $A$. batavus, $Q$. seminulum, $C$. lobatulus, Bulimina gibba and $B$. marginata. The isotopic data are presented in Tables 2 and 3 alongside the temperature and salinity values measured for each site and the maximum and minimum temperatures recorded at these sites over the annual cycle (Elliott et al., 1991). As there were many more dead individuals of a species than live (stained) at most sites (Scott $e t$ al., 2003), measurements of live samples were not always possible for every species at every site studied. In addition, the live specimens of some species, notably $C$. lobatulus and $Q$. seminulum, were also often smaller.

\section{Discussion}

\section{Comparison of isotopic data from dead and live assemblages}

It is clear from the plot comparing live and dead $\delta^{18} \mathrm{O}_{\text {foram }}$ from the same samples (Figure 4) that the majority of the samples fall below the $\mathrm{x}=\mathrm{y}$ line. Assuming equilibrium precipitation this implies either that most of the dead assemblage was reworked from a warmer or less saline area or that the greatest contribution to the dead assemblage was made at a different time of the year when temperatures were higher or salinities lower than those recorded at the time of collection. Similar inferences can be made from examination of the $\delta^{13} \mathrm{C}_{\text {foram }}$ data (Figure 4). Again assuming equilibrium precipitation, where values fall below the $1: 1$ line the implication is that either the dead specimens of that species calcified at a time or place of higher organic matter flux (rain rate) or lower oxygenation of the bottom waters (Berger and Vincent, 1986; McCorkle and Emerson, 1988) than recorded on the cruise, and vice versa. Alternatively, the foraminifera from the dead assemblage may have lived deeper in the sediment column (Grossman, 1984).

Figure 4 shows clearly that those samples from stratified settings are consistently more positive in $\delta^{18} \mathrm{O}_{\text {foram }}$ in both live and dead samples than those from mixed settings, notwithstanding the different species analysed. The $\delta^{13} C_{\text {foram data }}$ show the opposite trend, with samples from stratified settings recording less positive values than those from the mixed sector. These relationships support the general interpretation of the Celtic Sea palaeo stable isotopic data in terms of the 


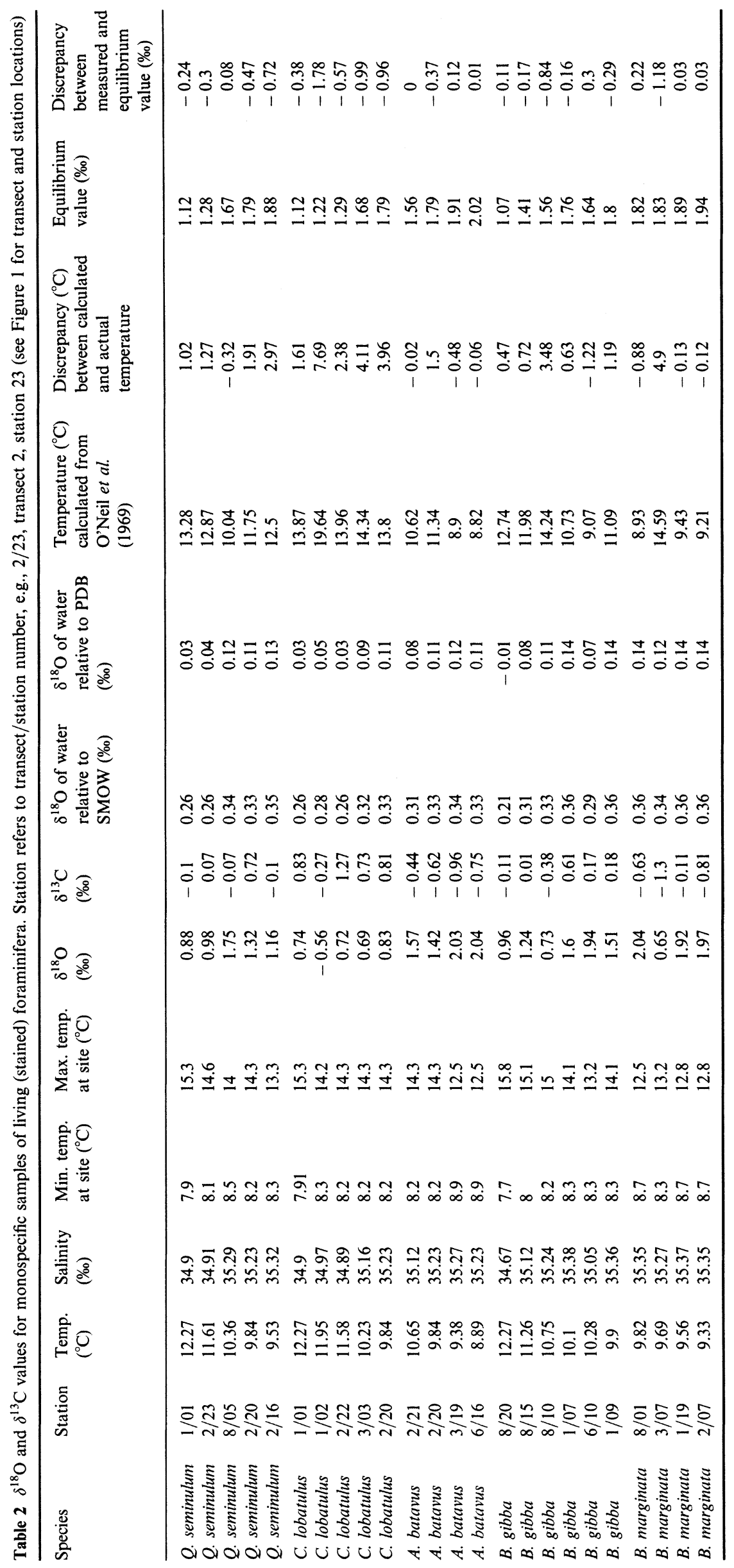




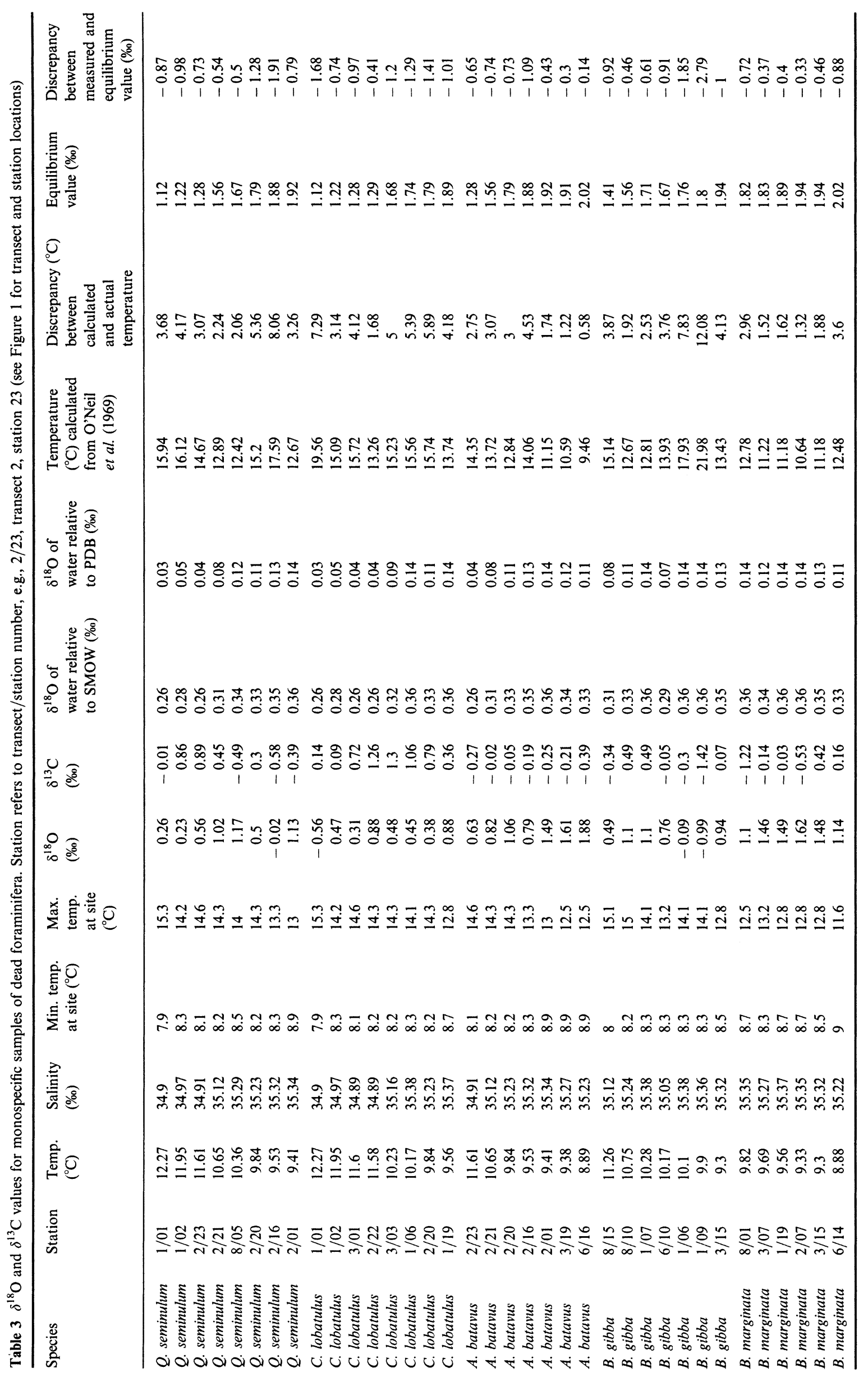



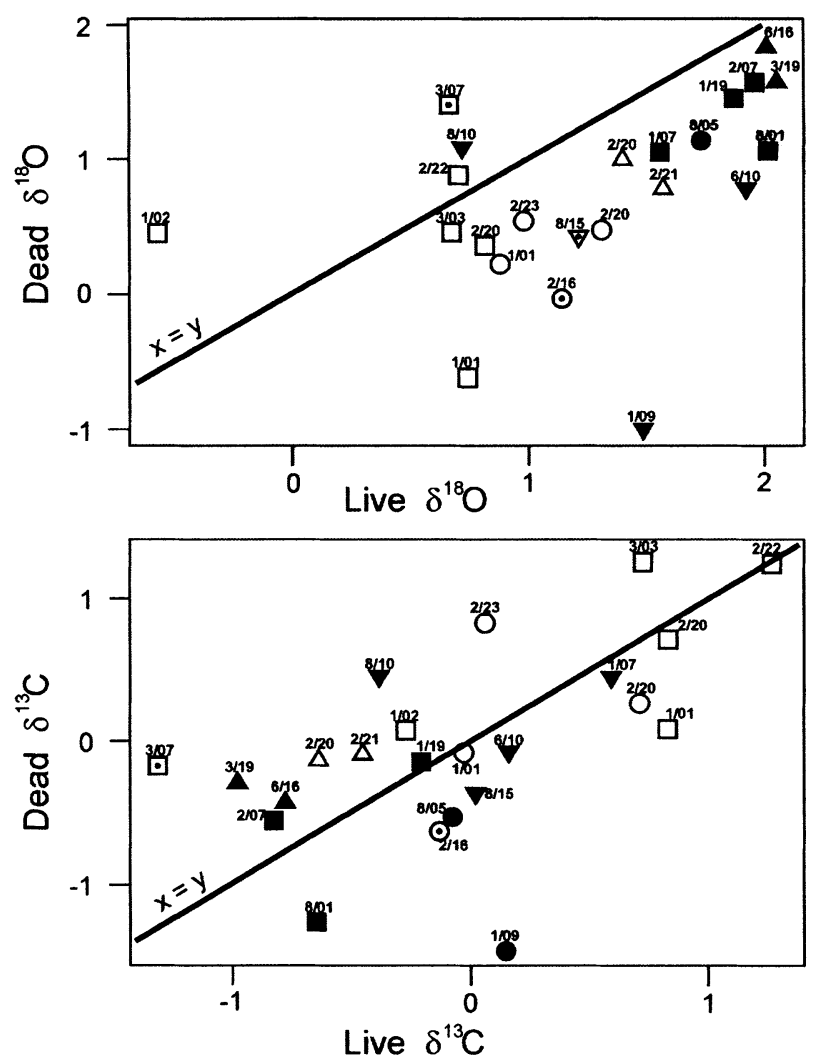

\begin{tabular}{|lllll|}
\hline Cibicides lobatulus & $\square$ & & \\
Bulimina marginata & & $\boldsymbol{\nabla}$ & $\boldsymbol{\square}$ \\
Quinqueloculina seminulum & $\bigcirc$ & $\bullet$ & $\odot$ \\
Bulimina gibba & $\nabla$ & $\boldsymbol{\nabla}$ & $\boldsymbol{\nabla}$ \\
Ammonia batavus & $\Delta$ & $\boldsymbol{\Delta}$ & \\
\hline
\end{tabular}

Figure 4 Comparison of the live and dead $\delta^{18} \mathrm{O}_{\text {foram }}$ (top) and $\delta^{13} \mathrm{C}_{\text {foram }}$ (bottom) for each species measured. In both plots samples from stratified settings are shown in black symbols, from mixed settings in unfilled symbols and from frontal settings in symbols containing dots.

replacement of tidally mixed by stratified water (Austin and Scourse, 1997). The specific $\delta^{18} \mathrm{O}_{\text {foram }}$ data for $A$. batavus and $Q$. seminulum (Figure 4) also reflect the offsets apparent in the palaeodata (Figure 2), with more positive values for $A$. batavus; it is this difference, here apparent from surface sample data, which Austin and Scourse (1997) interpreted from the palaeodata as the seasonal effect.

In the $\delta^{13} \mathrm{C}_{\text {foram }}$ data (Figure 4), A. batavus shows a consistent negative offset suggesting that this species calcifies generally when the bottom water is less oxygenated or when the rain rate of organic particles is higher (i.e., more stratified). Reworking is unlikely given that the offset is consistent for all samples despite their locations. $Q$. seminulum is consistently offset in the opposite direction, suggesting production, growth or derivation from a time of year or area of lower rain rate or higher oxygenation (i.e., less stratified). This interpretation of the $\delta^{13} \mathrm{C}$ data supports the notion of a seasonal effect separating these two species inferred from the Holocene $\delta^{18} \mathrm{O}$ data (Austin and Scourse, 1997; Figure 2) and might imply that this seasonal effect is also serving to separate the $\delta^{13} \mathrm{C}$ values for these two species in the Holocene record, a separation which Austin and Scourse (1997) attributed to the diagenetic microhabitat effect (cf. McCorkle et al., 1990).

\section{Isotopic disequilibria for individual species and} palaeotemperature reconstruction

To determine the $\delta^{18} \mathrm{O}$ disequilibrium value for each sample (the actual measurement less the equilibrium calcite value for that site) the $\delta^{18} \mathrm{O}$ value for water at each site has been calculated from salinity using the equation (Owen et al., 2002):

$$
\delta^{18} \mathrm{O}_{\text {seawater }}=-7.419+0.22 \mathrm{~S}
$$

where $\mathrm{S}=$ salinity and $\delta^{18} \mathrm{O}_{\text {seawater }}$ is the isotopic composition of the sea water relative to SMOW. This value converted to the VPDB scale and the temperature of the water at the various sites have been used to calculate $\delta^{18} \mathrm{O}_{\text {foram }}$ at equilibrium using a rearrangement of equation (2) (O'Neil et al., 1969). The $\delta^{18} \mathrm{O}$ disequilibrium values and the uncorrected, $\delta^{13} \mathrm{C}_{\text {foram }}$ values for each are presented in Figure 5; error bars to $1 \sigma$ are shown. Since the bottom-water DIC $\delta^{13} \mathrm{C}$ was not measured, the carbon values can only indicate in what region and over what range the various species precipitate rather than how they compare to equilibrium. The oxygen data are subject to the caveat regarding the chosen mixing-line equation adopted as discussed above.

Though there are few statistically significant differences between the species, the live $A$. batavus, of all the species examined, produced values closest to equilibrium, though the dead specimens, as with most of the species, were more negative than the live (Figure 5). C. lobatulus shows the strongest negative disequilibrium. The live $Q$. seminulum also show a negative disequilibrium; the site closest to equilibrium belongs to that group for which the mixing-line equation may not be appropriate. If compensation were made for this by using the alternative equation it would lie at around $-0.92 \%$, much closer to the other samples.

As with the $\delta^{18} \mathrm{O}$ data, the $\delta^{13} \mathrm{C}_{\text {foram }}$ data (Figure 5) show few statistically significant differences between species, though $Q$. seminulum and $C$. lobatulus appear to tend towards positive values and $A$. batavus and $B$. marginata towards negative values. This can probably be explained in terms of the microhabitat effect (McCorkle et al., 1990) since the sampling method used probably resulted in the recovery of shallow infaunal specimens. Certainly the buliminid species measured are regarded as infaunal rather than epifaunal in habitat, and $Q$. seminulum and $C$. lobatulus as epifaunal (Murray, 1991).

To examine what the oxygen disequilibria mean in terms of palaeotemperature calculations, the $\delta^{18} \mathrm{O}$ value for water at each site and the live $\delta^{18} \mathrm{O}_{\text {foram }}$ measurements on each species at the various sites have been used to calculate temperature using equation (2) (O'Neil et al., 1969) and the results plotted against the actual temperatures measured (Figure 6). Equilibrium precipitation is represented by the line $\mathrm{x}=\mathrm{y}$. The data are also plotted by oceanographic setting. This clearly shows the mixed-water samples with higher bottom-water temperatures than the stratified and demonstrates the ability of the $\delta^{18} \mathrm{O}_{\text {foram }}$ data to detect this temperature gradient. The calculated temperatures are close to those measured from the stratified sector, but there is a tendency for the calculated temperatures to be higher than those measured from the mixed sector.

It is obvious from this that, of all the species, $A$. batavus is the primary candidate for equilibrium precipitation. This might also be the case for $B$. marginata if allowance is made for the single outlier. These data suggest that $Q$. seminulum overestimate temperature by around $2^{\circ} \mathrm{C}$ and that palaeotemperature calculations based on $C$. lobatulus and $B$. gibba might also be exaggerated. The general pattern is for overestimation of temperature. This disequilibrium for $Q$. seminulum might explain some of the offset between this species and $A$. batavus recorded in the Holocene data, and attributed by Austin and 
$\delta^{18} \mathrm{O}$ foram - equilibrium value

$\delta^{13} \mathrm{C}$ foram

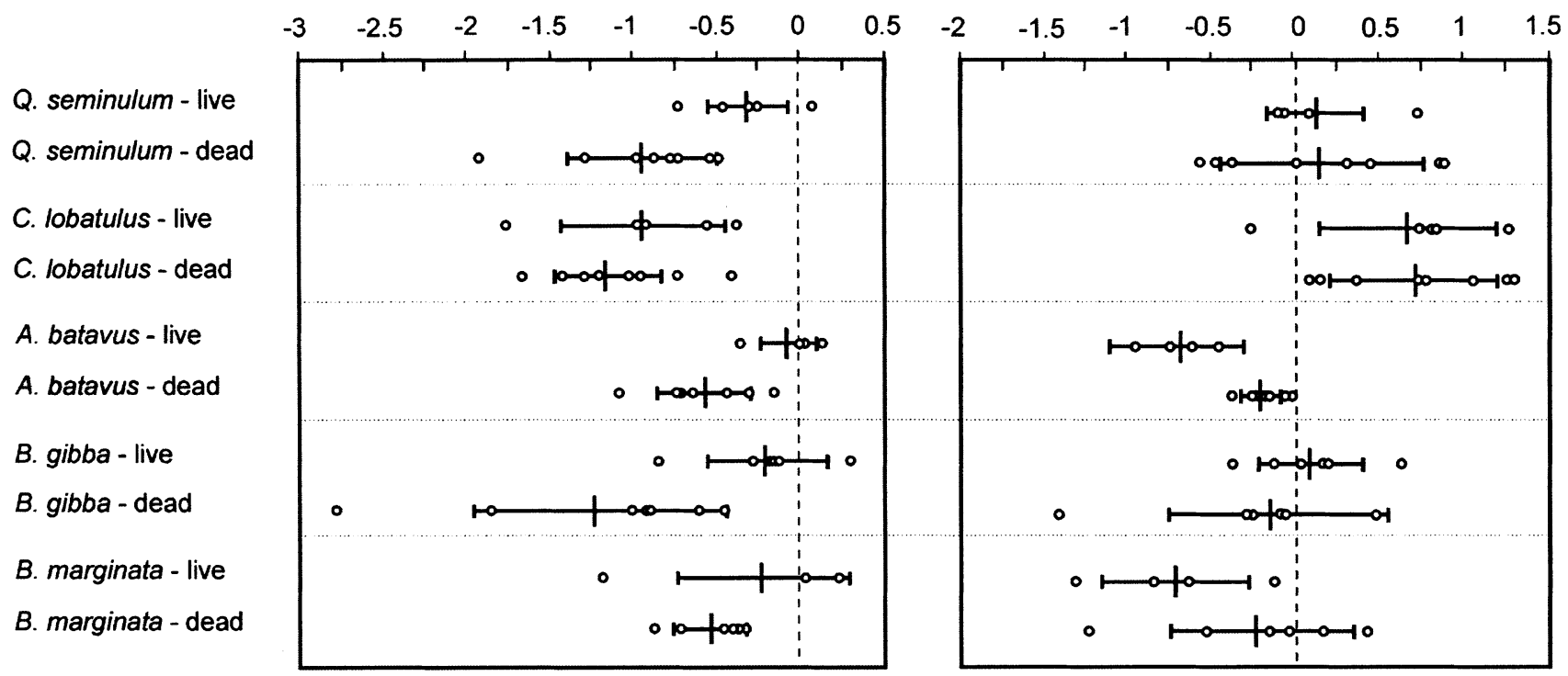

Figure $5 \delta^{18} \mathrm{O}$ isotopic disequilibria and $\delta^{13} \mathrm{C}$ of monospecific samples of live and dead foraminifera. Mean values indicated by large vertical bars and error bars shown at $1 \sigma$.

Scourse (1997) to the seasonal effect. It is nevertheless clear that $\delta^{18} \mathrm{O}_{\text {foram }}$ measurements from the Celtic Sea are related to summer bottom-water temperatures and can therefore be used as a tool to reconstruct seasonal stratification dynamics, and so support the first hypothesis presented above. This also supports the notion, assumed in Austin and Scourse (1997), that test calcification occurs largely during the summer months.

\section{The 'seasonal effect'}

Figure 7 shows the temperatures calculated using the O'Neil et al. (1969) equation and the measurements on the dead

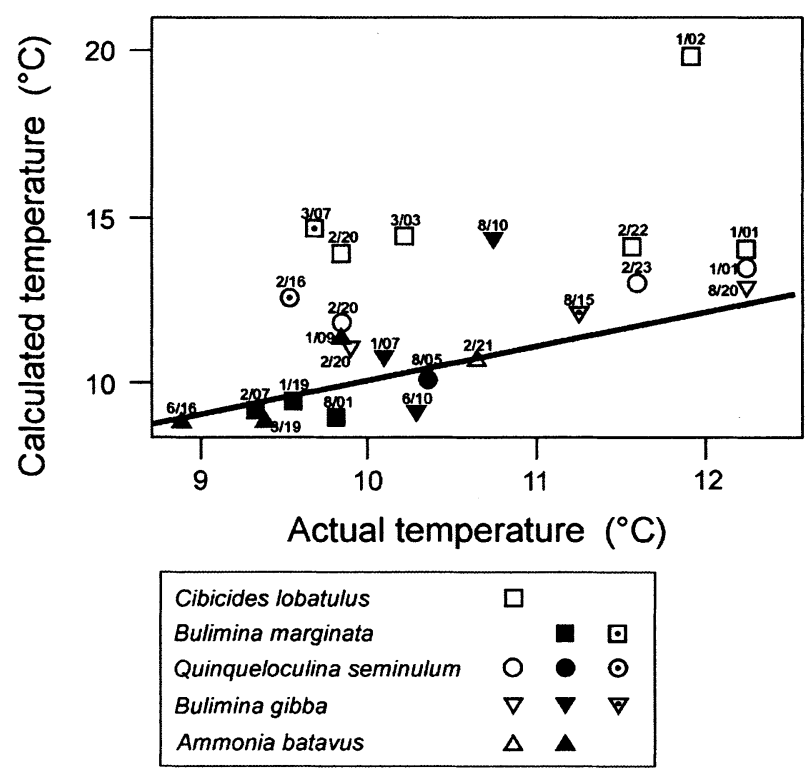

Figure 6 Measured bottom-water temperatures plotted against temperatures calculated from live $\delta^{18} \mathrm{O}_{\text {foram values. Samples from stratified }}$ settings are shown in black symbols, from mixed settings in unfilled symbols and from frontal settings in symbols containing dots. $\delta^{18} \mathrm{O}_{\text {foram }}$ for each species plotted against the actual temperatures measured for each site. The same axis are then reused to plot the lines which represent the warmest and coldest bottom-water conditions experienced annually at these sites (Elliott et al., 1991) so that the temperatures on the $\mathrm{x}$ axis become sites and the $y$ axis becomes measured temperature. The mixed sites show the greatest annual range in temperatures. At all sites the highest temperatures are recorded in September and the lowest in February.

On the right-hand side of the $Q$. seminulum plot (Figure 7a) are three mixed sites and to the left two stratified, with the remainder being frontal. As the live $\delta^{18} \mathrm{O}_{\text {foram }}$ data suggest that this species may overestimate temperatures by $2^{\circ} \mathrm{C}$, this may explain why many of the samples lie above even the maximum temperatures experienced at a site during the annual cycle; even allowing for this, one outlier is too high by several degrees. The data suggest that this species calcifies generally during peak temperatures, i.e., in September (Figure 8). The overestimation of temperature suggested for $C$. lobatulus is supported by these data (Figure $7 \mathrm{~b}$ ) and, if a disequilibrium correction is applied, would suggest that this species also calcifies during peak late-summer temperatures; B. gibba (Figure 7d) and $B$. marginata (Figure $7 \mathrm{e}$ ) show similar patterns. The data for $A$. batavus (Figure 7c), however, indicates that individuals in stratified sites calcify during peak late summer, while those from mixed sites precipitate calcite in spring or early summer when temperatures are cooler. The triggers for growth and/or or reproduction of this species occur during spring in the mixed sector and during late summer/autumn on the stratified side. Alternatively, it is possible that in each of these species calcification occurs over a wider time interval, but that during these identified parts of the temperature cycle the nature of calcification, e.g., crystal structure, test wall thickness, inhibits test dissolution and/or destruction and thereby maximizes preservation potential. Thus isotopic measurements from these preferentially preserved specimens will provide a proxy measure only for these specific parts of the cycle. Whether production or preservation, these data nevertheless highlight a seasonal component related to calcification which will be reflected in any geochemical analyses of the tests of these species. 
(a)

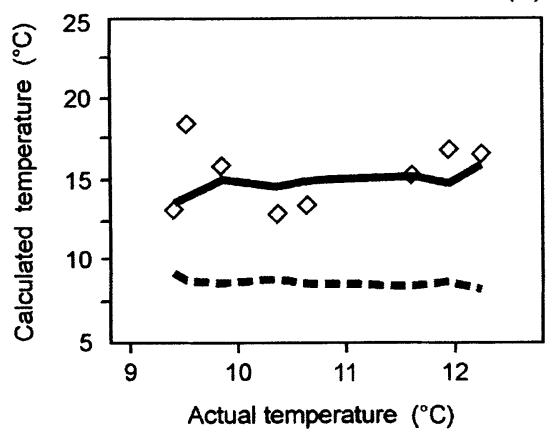

(d)

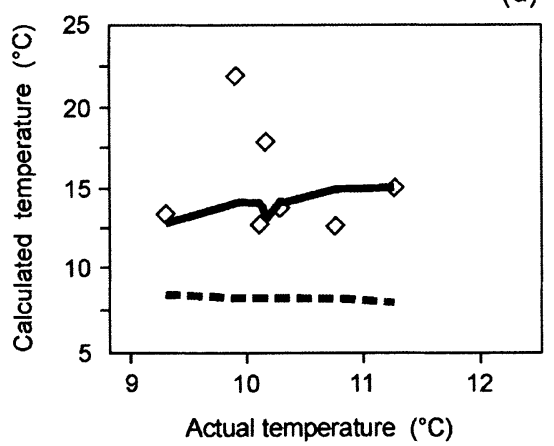

(b)

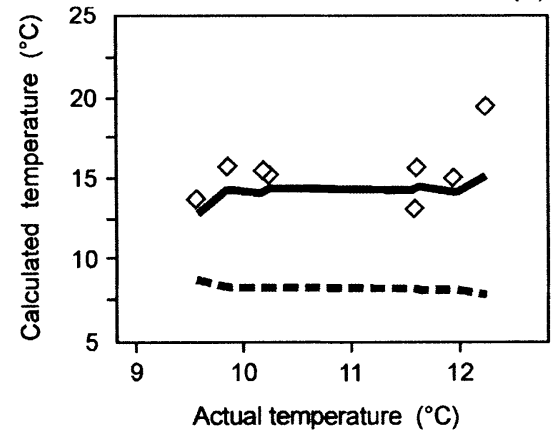

(e)

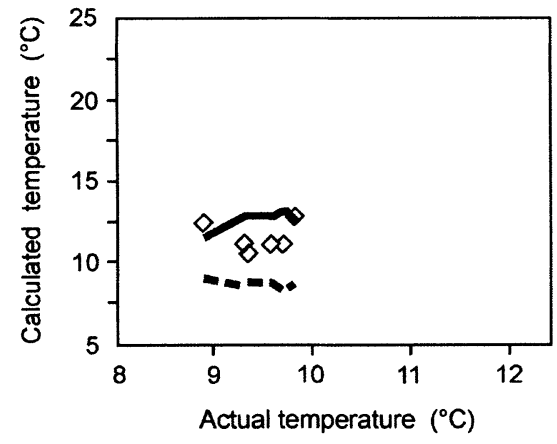

(c)

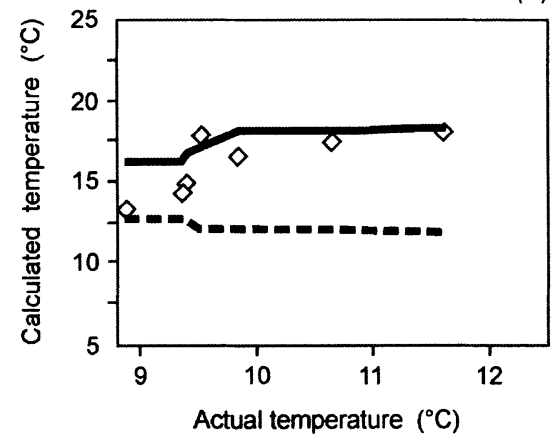

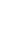

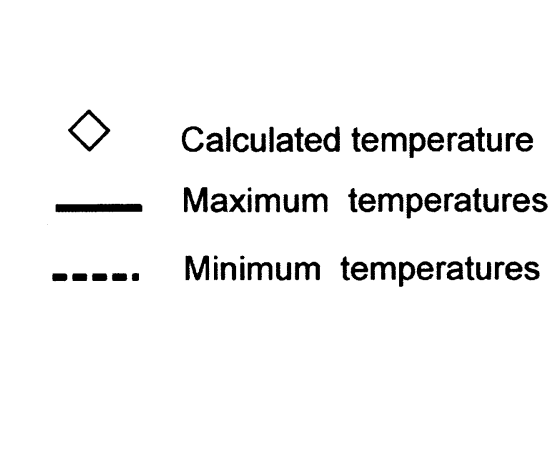

Figure 7 Individual species plots of actual temperatures at the time of sampling against temperatures calculated from dead $\delta^{18} \mathrm{O}_{\text {foram }}$ calcite and a comparison of these data with the maximum and minimum temperatures experienced at the sampling stations plotted on the same axis as 'calculated temperature' (Elliott et al., 1991) for (a) Q. seminulum; (b) C. lobatulus; (c) A. batavus; (d) B. gibba; (e) B. marginata.

Taken together, these data from the dead assemblages support the conclusion from the live specimens that test calcification and/or preservation, for all species, occurs generally during the warmest bottom-water temperatures of the year during the summer months, an assumption used by Austin and Scourse (1997) to reconstruct bottom-water palaeotemperatures. The $A$. batavus data further suggest that different species calcify at, or are preserved from, different stages within the warm part of the temperature cycle and therefore support the notion of a seasonal effect first described by Austin and Scourse (1997). Comparison of the A. batavus and $Q$. seminulum data highlight this seasonal effect and, along with the vital effect described for $Q$. seminulum above, explain why the $\delta^{18} \mathrm{O}$ records for these two species from the Holocene sequence presented in Austin and Scourse (1997) are offset. They were, however, incorrect in attributing the more positive record for $A$. batavus to apparently cooler bottom water because it is clear from measured bottom-water temperatures from the

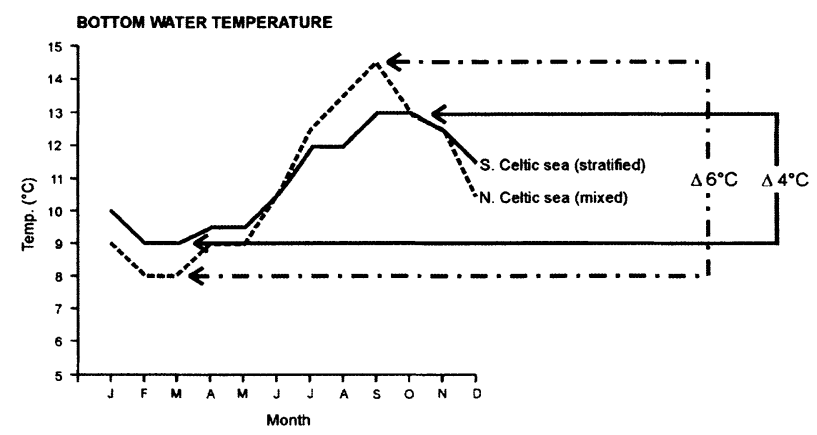

Figure 8 The annual bottom-water temperature cycles for (a) the southern Celtic Sea (stratified during summer) and (b) the northern Celtic Sea (mixed throughout the year) (data from Elliott et al., 1991).
Celtic Sea (Elliott et al., 1991) that, in the stratified sector, the summer bottom-water temperatures are higher than the winter bottom-water temperatures from the same sector when the water mass is seasonally mixed (Figure 8). This means that spring-summer calcification for $A$. batavus will result in a more positive record than for $Q$. seminulum which is a peak summer calcifier.

\section{Conclusions}

(1) Comparison of live and dead $\delta^{18} \mathrm{O}_{\text {foram }}$ data from surface samples taken in transects across the Celtic Sea front demonstrates either that the dead assemblages contain a significant quantity of reworked specimens from either a warmer or a more saline region or that the greatest contribution to the dead assemblages was at a time of year when temperatures and salinities were different to that during sample collection.

(2) Samples from stratified settings are characterized by more positive $\delta^{18} \mathrm{O}_{\text {foram }}$ and less positive $\delta^{13} \mathrm{C}_{\text {foram }}$ values than the mixed samples. This confirms the value of stable isotopic measurements as a tool in shelf-sea palaeostratification investigations.

(3) Offsets in $\delta^{18} \mathrm{O}_{\text {foram }}$ and between $A$. batavus and $Q$. seminulum support the notion of the seasonal effect postulated by Austin and Scourse (1997).

(4) A. batavus produces values close to equilibrium while other species show a negative disequilibrium and therefore a tendency to overestimate temperature. $Q$. seminulum overestimates temperature by up to $2^{\circ} \mathrm{C}$ and this might explain some of the offset observed between this species and $A$. batavus observed by Austin and Scourse (1997).

(5) Comparison of the $\delta^{18} \mathrm{O}_{\text {foram }}$ data with measured seasonal temperature cycles from mixed and stratified localities in 
the Celtic Sea demonstrates that, while most foraminifera calcify during the summer months, different species calcify at different times within this warm part of the seasonal cycle; $Q$. seminulum calcifies during September when peak bottom-water temperatures occur, while A. batavus calcifies during September in stratified localities, but during spring or early summer in mixed localities. Alternatively, the data might indicate differences in preservation potential linked to seasonal control of calcification.

We therefore conclude that (1) benthic foraminiferal stable isotopes from across the Celtic Sea front reflect seasonal stratification and (2) offsets in the Celtic Sea $\delta^{18} \mathrm{O}$ palaeorecord between different species are the result of the seasonal effect in which different species calcify at, or are preserved from, different times of the year; the data further suggest that this effect is complicated by the oceanographic context in which the species live. This study confirms the interpretation of the $\delta^{18} \mathrm{O}$ palaeodata from the Celtic Sea as a palaeostratification record (Austin and Scourse, 1997) and demonstrates that $\delta^{18} \mathrm{O}$ data from shelf-sea cores can be used to supplement benthic foraminiferal assemblages (Scott et al., 2003) as a tool for reconstructing the long-term dynamics of seasonal stratification.

\section{Acknowledgements}

The authors thank the officers and crew of the RV Prince Madog for assistance both during and after the research cruises, and Anne Hammerstein, Ian Pritchard, Emily Roberts, Iain McMyn, John McDonagh and Grant Fulton for their help at sea. Paul Kennedy, Richard Owen and Gideon Middleton are thanked for their help in running the water isotope samples at Bangor, Sandy Tudhope for running the dead foraminiferal isotope samples at the University of Edinburgh and Mike Hall for running the live foraminiferal isotope samples at the University of Cambridge. Brian Long is thanked for his work in helping to prepare the text and draughting the figures. The comments of Professor Dick Kroon (University of Amsterdam) on aspects of this research have proved very valuable. Discussion with Charles Baker, Neil Bridgstock, Natalie Edgar, Emily Kirby and Sara Kate Watson is also acknowledged.

\section{References}

Altenbach, A.V. 1992: Short term processes and patterns in the foraminiferal response to organic flux rates. Marine Micropaleontology 19, 119-29.

Alve, E. and Murray, J. 1994: Ecology and taphonomy of benthic foraminifera in a temperate mesotidal inlet. Journal of Foraminiferal Research 24, 18-27.

Austin, W.E.N. and Evans, J.R. 2000: North East Atlantic benthic foraminifera: modern distribution patterns and palaeoecological significance. Journal of the Geological Society of London 157, 679-91.

Austin, W.E.N. and Scourse, J.D. 1997: Evolution of seasonal stratification in the Celtic Sea during the Holocene. Journal of the Geological Society of London 154, 249-56.

Bé, A.W.H., Hemleben, C., Anderson, O.R. and Spindler, M. 1979: Chamber formation in planktonic foraminifera. Micropaleontology 25, 294-307.

Berger, W.H. and Vincent, E. 1986: Deep-sea carbonates: reading the carbon isotope signal. Geologische Rundschau 75, 249-69.

Berger, W.H., Fisher, K., Lai, C. and Wu, G. 1989: Ocean productivity and palaeoproductivity: an overview. In Berger, W.H., Smetacek, V.S. and Wefer, G., editors, Productivity of the ocean: present and past, Chichester: Wiley, 1-67.

Bowers, D.G. and Simpson, J.H. 1990: Geographical variations in the seasonal heating cycle in northwest European shelf seas. Continental Shelf Research 10, 185-99.

Craig, H. 1957: Isotopic standards for carbon and oxygen and correction factors for mass-spectrometric analysis of carbon dioxide. Geochimica et Cosmochimica Acta 12, 133-49.

Debenay, J.P., Guillou, J.J., Geslin, E. and Lesourd, M. 2000: Crystallization of calcite in foraminiferal tests. Micropaleontology 46, 87-94.

Elliott, A.J., Clarke, T. and Li, Z. 1991: Monthly distributions of surface and bottom water temperatures in the northwest European shelf seas. Continental Shelf Research 11, 453-66.

Epstein, S. and Mayeda, T. 1953: Variations of ${ }^{18} \mathrm{O}$ content of waters from natural sources. Geochimica et Cosmochimica Acta 4, 213-24.

Frew, R.D., Dennis, P.F., Heywood, K.J., Meredith, M.P. and Boswell, S.M. 2000: The oxygen isotopic composition of water masses in the northern North Atlantic. Deep Sea Research Part 147 , 2265-80.

Friedman, I. and O'Neil, J.R. 1977: Compilation of stable isotope fractionation factors of geochemical interest. Data of Geochemistry (sixth edition, edited by M. Fleischer). Washington DC: United States Geology Survey. US Geology Survey Professional Paper 776, 1-37.

Gooday, A.J. 1994: The biology of deep-sea foraminifera: a review of some recent advances and their applications to paleoceanography. Palaios 9, 14-31.

Grossman, E.L. 1984: Carbon isotope fractionation in live benthic foraminifera - comparison with live inorganic precipitate studies. Geochimica et Cosmochimica Acta 48, 1505-12.

Hansen, H.J. 1999: Shell construction in modern calcareous foraminifera. In Se Gupta, B.K., editor, Modern foraminifera, Dordrecht: Kluwer, 57-70.

Haynes, J.R. 1973: Cardigan Bay Recent foraminifera. Bulletin of the British Museum (Natural History) Zoology Supplement 4, 1-245.

Hemleben, C., Spindler, M. and Anderson, O.R. 1989: Modern planktonic foraminifera. Berlin: Springer Verlag.

Lampitt, R. 1985: Evidence for the seasonal deposition of detritus to the deep-sea floor and its subsequent resuspension. Deep-Sea Research 32, 885-97.

Loubere, P. and Fariduddin, M. 1999: Quantitative estimation of global patterns of surface ocean biological productivity and its seasonal variation on time scales from centuries to millennia. Global Biogeochemical Cycles 13, 115-33.

McCorkle, D.C. and Emerson, S.R. 1988: The relationship between porewater carbon isotopic composition and bottomwater oxygen concentration. Geochimica et Cosmochimica Acta 52, $1169-78$.

McCorkle, D.C., Keigwin, L.D., Corliss, B.H. and Emerson, S.R. 1990: The influence of microhabitats on the carbon isotopic composition of deep-sea benthic foraminifera. Paleoceanography 5, 161-85.

Meldgaard, S. and Knudsen, K.L. 1991: Metoder til indsampling og oparbejning af prøver til foraminifer-analyser. Dansk Natur Dansk Skole, Genoptrykt på Fysisk Institut, 48-57.

Middleburg, J., Vlug, T. and van der Nat, F. 1993: Organic matter mineralization in marine systems. Global Planetary Change 8, 47-58. Murray, J.W. 1971: An atlas of British recent foraminiferids. London: Heinemann.

- 1991: Ecology and palaeoecology of benthic foraminifera. London: Longman.

- 2000: Revised taxonomy, atlas of British recent foraminiferids. Journal of Micropalaeontology 19, 44.

O'Neil, J.R., Clayton, R.N. and Mayeda, T.K. 1969: Oxygen isotope fractionation in divalent metal carbonates. Journal of Chemical Physics 31, $5547-58$.

Owen, R., Kennedy, H. and Richardson, C.A. 2002: Field investigation into partitioning of stable oxygen and carbon isotopes between Pecten maximum calcite and seawater. Geochimica et Cosmochimica Acta 66, 1727-37.

Pugh, D.T. and Thompson, K.R. 1986: The subtidal behaviour of the Celtic Sea - 1. Sea-level and bottom pressures. Continental Shelf Research 5, 293-319. 
Scott, G.A., Scourse, J.D. and Austin, W.E.N. 2003: The distribution of benthic foraminifera in the Celtic Sea: the significance of seasonal stratification. Journal of Foraminiferal Research 33, 32-61.

Scourse, J.D., Austin, W.E.N., Long, B.T., Assinder, D.J. and Huws, D. 2002: Holocene evolution of seasonal stratification in the Celtic Sea refined age model, mixing depths and foraminiferal stratigraphy. Marine Geology 191, 119-45.

Simpson, J.H. and Bowers, D. 1979: Shelf sea fronts adjustments revealed by satellite IR imagery. Nature $280,648-51$.

Smout, A.H. 1954: Lower Tertiary foraminifera of the Qatar peninsula. London: British Museum (Natural History).
Sverdrup, H.U. 1953: On conditions for the vernal blooming of phytoplankton. Journal du Conseil International pour l'Exploration de la $\mathrm{Mer}$ 18, 287-95.

Walsh, J.J., Rowe, G.T., Iversen, R.L. and McRoy, C.P. 1981: Biological export of shelf carbon is a sink of the global $\mathrm{CO}_{2}$ cycle. Nature 291 , 196-201.

Wollast, R. 1991: The coastal organic carbon cycle: fluxes, sources and sinks. In Mantoura, R.F.C., Martin, J.M. and Wollast, R., editors, Ocean margin processes in global change, Chichester: Wiley, $365-81$. 